\title{
Chemical and microbiological characterization of alheira: A typical Portuguese fermented sausage with particular reference to factors relating to food safety
}

\author{
Vânia Ferreira, Joana Barbosa, Sandra Vendeiro, Ana Mota, Fátima Silva, \\ Maria João Monteiro, Tim Hogg, Paul Gibbs, Paula Teixeira * \\ Escola Superior de Biotecnologia, Universidade Católica Portuguesa, R. Dr António Bernardino de Almeida, 4200-072 Porto, Portugal
}

Keywords: Alheira; Fermented meat sausages; Microbiological parameters; Chemical composition; Biogenic amines

\begin{abstract}
Alheiras are traditional smoked naturally fermented meat sausages produced in the north of Portugal. They have not previously been characterized as to their chemical and microbiological status. $\mathrm{pH}$ and salt levels are insufficient to assure microbiological safety, there is ample opportunity for post-cooking contamination; the products require chill storage and cooking before consumption.

Heavy metals and biogenic amines were, in general, within accepted limits for meat products. Lactic acid bacteria comprised the major microflora (ca. 7-8 log cfu/g) with substantial counts of micrococci and enterococci (up to 7 log cfu/g). Escherichia coli, Staphylococcus aureus and Listeria spp. were detected in several samples.
\end{abstract}

\section{Introduction}

Fermented meat products are part of the daily diet in rural areas of Portugal and fashionable food products in urban centres whose market has been increasing in a significant way. The physicochemical and microbiological characteristics of some traditional meat products, mainly Spanish and Italian, have been studied by other research groups (e.g. Drosinos et al., 2005; Moretti et al., 2004; Santos et al., 2005). Little information, however, exists on the Portuguese products.

Fermented sausages are considered safe foods due to the reduction in $a_{w}$ and $\mathrm{pH}$ that occurs during processing and storage and inhibits the development of pathogenic bacteria. The probability that some of the pathogenic organisms could overcome the antimicrobial hurdles

\footnotetext{
${ }^{*}$ Corresponding author. Tel.: +351 22 5580095; fax: +351 225580111. E-mail address: paula@esb.ucp.pt (P. Teixeira).
}

imposed during processing and that they may be present in the final product has, however, been a concern for producers and those responsible for public health and has been the topic of study of several research groups. In fact, various gastrointestinal disease outbreaks associated with fermented meats were reported by Moore (2004). In addition to microbiological hazards, the presence of biogenic amines in fermented sausages has been reported (Suzzi \& Gardini, 2003). The excessive consumption of these amines can be a health concern (ten Brink, Damink, Joosten, \& in 't Veld, 1990).

Alheiras are traditional, smoked, naturally-fermented meat sausages, produced in the North of Portugal. The origin of alheiras goes back to the end of the fifteenth century and it is associated with the presence of Jewish communities in Trás-os-Montes, after they were banned from Castile in 1492. According to tradition, a type of sausage was developed which was similar in shape to those that were part of Christian cuisine, but which was stuffed with 
chicken and flour instead of pork meat and fat. In this way, the crypto-Jews escaped being identified by the inquisition because of their different eating habits. The recipe eventually became popular among Christians and nowadays, in addition to the home-made alheiras, more than 500 tons are produced annually by various commercial units, using pork as well as other types of meats (duck, turkey, partridge and veal), representing an important economic resource for the region (http://www. idrha.min-agricultura.pt/produtos_tradicionais/estatisticas/estatisticas.htm).

The objective of this study was the microbiological and chemical characterization of alheiras. Particular reference is made to factors which might influence the safe consumption of this food. The data presented will be valuable in exposure assessment exercises for a number of known chemical and microbiological hazards. The identification and the quantification of the properties that better describe the characteristics of this product are also important as alheiras are in the process of being given the status of a product from a protected denomination of origin.

\section{Materials and methods}

Alheiras vary considerably in their final compositions and production processes. The relevant common elements in the production process are the boiling of various meats in lightly salted and spiced water; soaking the thinly sliced bread in some of the broth, formed during the boiling of the meats, until it is soft enough; adding meat in small pieces, spices and olive oil and/or fat drippings to the bread/broth mixture; no adding of starter cultures; stuffing the paste into cattle intestinal or cellulose/based casings when everything is completely mixed and the salt and spices adjusted to the desirable taste (variable); smoking the formed horseshoe-shaped sausages (c.a. $15 \mathrm{~cm}$ long; \pm 60 , for 2-8 days). The shelf life of alheiras is about 1 month if stored at $4{ }^{\circ} \mathrm{C}$ in air or longer if the sausages are vacuum packed. Alheiras are cooked before consumption either by frying, grilling or boiling, according to regional traditions or consumer preferences.

\section{Sampling}

Alheiras from 12 different producers were collected from retail establishments during the period September 2003-May 2004. With the exception of two specific producers, which were only sampled once, samples were collected on at least two different occasions in order to have samples from two different batches. Samples were transported to the laboratory in portable, insulated cold-boxes and stored at $4{ }^{\circ} \mathrm{C}$ until they were analysed, normally between 1 and 5 days after collection. From each batch, six alheiras were divided into various pieces. For each parameter to be evaluated, unless otherwise stated, 2-4 independent analyses were performed using randomly selected pieces.

\section{Chemical analyses}

\section{General composition}

The approximate composition in terms of proteins, fat and carbohydrates was determined according to Slack (1997). Nitrite, nitrate, chloride and moisture contents were determined following the ISO Standards 2918 (1975a), 3091 (1975b), 1841-2 (1996a) and 1442 (1997), respectively. $\mathrm{pH}$ was determined directly with a Crison MicropH 2002 pH-meter (Crison, Barcelona, Spain) equipped with an InLab 427 puncture electrode (Mettler Toledo, Columbus, $\mathrm{OH}, \mathrm{USA}$ ).

\section{Lead, cadmium, arsenic and mercury determination}

Lead, cadmium, arsenic and mercury determination was by atomic absorption spectrometry. Arsenic was determined according to AOAC Methods (1997). Mercury was determined according to the European Standard EN 13806 (ECS, 2002). Cadmium and lead were determined according to the European Standard EN 14082 (ECS, 2003).

\section{Biogenic amines determination}

Ten grams of each sample of alheira were weighed into an $85 \mathrm{ml}$ test tube and extracted with $20 \mathrm{ml}$ of trichloroacetic acid $(5 \%)$. Extracts were derivatized with $o$-phthalaldeyde (OPA) and biogenic amines were determined by HPLC using a method based on that described by Komprda et al. (2004).

\section{Microbiological analyses}

Twenty-five grams samples were added to $225 \mathrm{ml}$ of sterile buffered peptone water (Merck, Darmstadt, Germany), and homogenized in a stomacher for $2 \mathrm{~min}$. Appropriate decimal dilutions were prepared in Ringer solution (LabM, Bury, UK) for microbial enumeration: lactic acid bacteria on de Man, Rogosa Sharpe Agar (MRS, LabM) and incubated at $30^{\circ} \mathrm{C}$ for $72 \mathrm{~h}$; Enterococcaceae on bile esculin azide agar (Biokar Diagnostics, Beauvais, France), incubated at $30{ }^{\circ} \mathrm{C}$ for $72 \mathrm{~h}$; Micrococcaceae on mannitol salt agar (Biokar Diagnostics), incubated at $37^{\circ} \mathrm{C}$ for $48 \mathrm{~h}$; yeasts and moulds on rose-bengal agar supplemented with $0.1 \mathrm{~g} / \mathrm{L}$ of chloramphenicol (Oxoid, Hampshire, UK), incubated at $25^{\circ} \mathrm{C}$ for 5 days; Escherichia coli on TBX (BioRad, CA, USA), incubated at $44{ }^{\circ} \mathrm{C}$ for $24 \mathrm{~h}$; coagulase-positive staphylococci on Baird-Parker RPF-agar (bioMérieux, Marcy l'Etoile, France), incubated at $37^{\circ} \mathrm{C}$ for $48 \mathrm{~h}$; Enterobacteriaceae according to ISO 21528-2 (2000); sulphite reducing Clostridium spores according to the Portuguese Standard NP 2262 (IPQ, 1986).

Enumeration of Listeria spp. was performed by the most probable number (MPN) technique using culture media referred to in ISO 11290-1 (1996b), namely Demi-Fraser broth, Fraser broth and Palcam medium. The MPN of Listeria spp. in each sample was determined using the FDA 
online MPN table (www.cfsan.fda.gov/ ebam/bam-a2. html).

\section{Results and discussion}

\section{Chemical analysis}

The results of the physicochemical analyses are shown in Table 1. Generally, these indicated that, according to the generally accepted limits for these parameters, $\mathrm{pH}$, salt content and humidity per se, do not assure the microbiological safety of this product. The meats in this product are boiled sufficiently to inactivate the vegetative pathogens, but post-process contamination can occur via the addition of the bread and spices and by subsequent handling during filling and later manipulations.

For all samples analysed, nitrate and nitrite concentrations were lower than the accepted limits for these parameters (European Commission, 1995), 250 and $100 \mathrm{mg} / \mathrm{kg}$, respectively. It is noteworthy that, unlike many similar products, alheiras are not traditionally prepared using nitrate or nitrite and thus it is expected that the concentration of these compounds will be very low.

\section{Lead, cadmium, arsenic and mercury}

Maximum permitted levels of cadmium and lead in meats, as defined in Commission Regulation No. 466/ 2001 , are 0.05 and $0.1 \mathrm{mg} / \mathrm{kg}$, respectively. With the exception of one sample out of two analysed from producer 10 in which the lead concentration was $0.6 \mathrm{mg} /$ $\mathrm{kg}$, the legislated maximum value was never exceeded (Table 2). High lead concentrations in a Greek fermented meat product, $0.7750 \mathrm{mg} / \mathrm{kg}$, have also been reported by the Directorate-General Health and Consumer Protection (2004).

There is no legislation in force controlling arsenic in foods within the EU. Levels found in the present study, with the exception of samples from producer 1 in which mean arsenic concentration of three different products was $0.061 \mathrm{mg} / \mathrm{kg}$ (Table 2), are in the range of values reported by the Directorate-General Health and Consumer Protection (2004) for meat and meat products produced in Denmark, Germany, Ireland and the UK, 0.0037$0.033 \mathrm{mg} / \mathrm{kg}$.

Table 1

Minimum, maximum, mean and standard deviation of physicochemical parameters and composition of alheira

\begin{tabular}{lrrcc}
\hline & Min. & Max. & Mean & SD \\
\hline $\mathrm{pH}$ & 4.5 & 6.3 & 5.11 & 0.5 \\
\% NaCl & 1.0 & 1.8 & 1.3 & 0.3 \\
\% Moisture & 43.3 & 57.2 & 52.3 & 4.31 \\
\% Fat & 10.9 & 29.6 & 18.4 & 4.7 \\
\% Total protein & 6.9 & 15.5 & 11.4 & 2.8 \\
\% Carbohydrates & 10.2 & 20.9 & 15.2 & 3.6 \\
Energy (kcal/100 g) & 220 & 369 & 274.4 & 39.7 \\
\hline
\end{tabular}

There is no legislation in force controlling mercury in foods within the EU. Levels found in the present study, are in the range of values reported by the Directorate-General Health and Consumer Protection (2004) for meat and meat products produced in Denmark, France, Germany, Ireland and UK $0.0015-0.012 \mathrm{mg} / \mathrm{kg}$ (Table 2) well below the maximum level defined in Commission Regulation No. 466/2001 for bivalves, cephalopods and crustaceans, $0.5 \mathrm{mg} / \mathrm{kg}$.

\section{Biogenic amines}

A great variability was observed in the biogenic amines content of the products from different producers and even from two batches of the same producer (Table 3). A high variability in the biogenic amines content was previously reported for sausages produced by different manufacturers (Tschabrun, Sick, Bauer, \& Kranner, 1990) and for different batches of the same commercial products (HernándezJover, Izquierdo-Pulido, Veciana-Nogués, Mariné-Font, \& Vidal-Carou, 1997). Tyramine, ethylamine and 2-phenylethylamine were the biogenic amines with the highest concentrations in the samples analyzed. Tyramine has been systematically reported as the most abundant amine in fermented sausages (Coïsson, Cerutti, Travaglia, \& Arlorio, 2004; Komprda et al., 2004). The presence of 2-phenylethylamine only occurred when tyramine was also detected. This correlation was also observed by other researchers (Ansorena et al., 2002) and has been attributed to the non-specific activity of tyrosine decarboxylase (Joosten, 1988). The toxic level of tyramine is $100-800 \mathrm{mg} / \mathrm{kg}$ (Silla-Santos, 1996). Accordingly, and based on the present results, biogenic amines in alheiras apparently do not represent an obvious or generalised hazard.

\section{Microbiological analyses}

Concerning the microbiological status of the products, as shown in Tables 4 and 5, great variability was observed between producers and even between lots from the same producer. These might be the result of small differences in the processes, as alheiras from different localities were sampled and also because the age of the various samples is certainly different (and not known - they were obtained from the local retail market and sold "loose" so that neither the production date nor the "best before" date are labelled).

It is obvious that lactic acid bacteria (LAB) were the dominant microflora (Table 4). Counts on MRS and M17 were, in most cases, higher than $7.5 \log \mathrm{cfu} / \mathrm{g}$ with the exception of samples from producer 6 , where counts on MRS and M17 were 6.9-7.4 and 6.6-7.4 log cfu/g, respectively. With the exception of samples from producers 5 and 6 , and one sample from producer 2 , counts on mannitol salt agar were higher than $\log 6.5 \log \mathrm{cfu} / \mathrm{g}$. LAB and gram-positive, catalase-positive cocci have been demonstrated to have an important role in the manufacture of various traditional fermented sausages (Moretti et al., 
Table 2

Lead, cadmium, arsenic and mercury concentration in alheira $\left(10^{-3} \mathrm{mg} / \mathrm{kg}\right)$

\begin{tabular}{|c|c|c|c|c|c|c|c|c|c|c|c|c|}
\hline & \multicolumn{12}{|l|}{ Producer } \\
\hline & 1 & 2 & 3 & 4 & 5 & 6 & 7 & 8 & 9 & 10 & 11 & 12 \\
\hline Lead & $25 \pm 20$ & 40 & $19 \pm 2$ & 34 & 25 & 25 & $30 \pm 3$ & $23 \pm 5$ & $24 \pm 6$ & $298 \pm 388$ & $35 \pm 14$ & $32 \pm 17$ \\
\hline Cadmium & $9 \pm 2$ & 10 & $8 \pm 3$ & 13 & 8 & 8 & $5 \pm 1$ & $7 \pm 4$ & $5 \pm 1$ & $7 \pm 4$ & $7 \pm 1$ & $7 \pm 1$ \\
\hline Mercury & $<40$ & $<50$ & $<40$ & $<50$ & $<80$ & $<80$ & $<20$ & $<40$ & $<20$ & $<20$ & $<40$ & $<40$ \\
\hline
\end{tabular}

Table 3

Biogenic amine content found in allheira $(\mathrm{mg} / \mathrm{kg})$

\begin{tabular}{lllcccccc}
\hline Producer/lot & Histamine & Methylamine & Ethylamine & Tyramine & 2-Phenylethylamine & Putrescine & Isoamylamine & Cadaverine \\
\hline 10/A & 1.5 & 0.1 & 0 & 21.8 & 77.5 & 2.6 & 0.0 & 3.2 \\
10/B & 0.1 & 0.0 & 11.0 & 0.7 & 0.0 & 0.0 & 0.0 & 0.0 \\
3/A & 0.4 & 0.4 & 1.2 & 41.1 & 8.4 & 4.2 & 0.0 \\
9/A & 3.0 & 0.7 & 4.5 & 63.2 & 9.7 & 6.2 & 0.0 & 3.7 \\
8/A & 0.1 & 0.1 & 15.6 & 1.1 & 0.0 & 0.0 & 0.0 & 0.7 \\
8/B & 0.2 & 0.1 & 21.1 & 2.6 & 0.0 & 0.4 & 0.0 & 0.0 \\
\hline
\end{tabular}

Table 4

Microbiological characterization of alheira: important microbial parameters in fermented products

\begin{tabular}{|c|c|c|c|c|c|c|c|}
\hline Producer & Lot & $\begin{array}{l}\text { Counts in MRS } \\
(\log \mathrm{cfu} / \mathrm{g})\end{array}$ & $\begin{array}{l}\text { Counts in M17 } \\
(\log \mathrm{cfu} / \mathrm{g})\end{array}$ & $\begin{array}{l}\text { Counts in MSA } \\
(\log \mathrm{cfu} / \mathrm{g})\end{array}$ & $\begin{array}{l}\text { Enterococci } \\
(\log \mathrm{cfu} / \mathrm{g})\end{array}$ & $\begin{array}{l}\text { Yeasts } \\
(\log \mathrm{cfu} / \mathrm{g})\end{array}$ & $\begin{array}{l}\text { Moulds } \\
(\log \mathrm{cfu} / \mathrm{g})\end{array}$ \\
\hline \multirow[t]{2}{*}{1} & A & $8.9 \pm 0.1$ & $8.8 \pm 0.0$ & $6.3 \pm 0.0$ & $6.5 \pm 0.5$ & (ND) & (ND) \\
\hline & $\mathrm{B}$ & $5.9 \pm 0.1$ & $6.0 \pm 0.0$ & $6.3 \pm 0$ & $5.7 \pm 0.0$ & $2.9 \pm 0.2$ & $<1$ \\
\hline \multirow[t]{2}{*}{2} & A & $8.8 \pm 0.2$ & $8.5 \pm 0.1$ & $4.3 \pm 0.3$ & $7.8 \pm 0.1$ & (ND) & (ND) \\
\hline & B & $8.6 \pm 0.0$ & $7.6 \pm 1.8$ & $>6.2$ & $8.1 \pm 0.5$ & $5.8 \pm 0.1$ & $<1$ \\
\hline \multirow[t]{2}{*}{4} & A & $7.7 \pm 0.0$ & $7.9 \pm 0.0$ & $5.9 \pm 0.1$ & $7.0 \pm 0.1$ & $3.9 \pm 0.2$ & $3.2^{\mathrm{a}}$ \\
\hline & B & $7.5 \pm 0.3$ & $7.6 \pm 0.2$ & $5.9 \pm 0.1$ & $4.5 \pm 0.3$ & $4.0 \pm 0.72$ & $<1$ \\
\hline 5 & A & $7.7 \pm 0.4$ & $7.5 \pm 0.5$ & $<1$ & $6.7 \pm 0.5$ & $3.7 \pm 0.3$ & $1.8 \pm 0.1$ \\
\hline 6 & A & $7.0 \pm 0.3$ & $7.0 \pm 0.3$ & $<1$ & $4.3 \pm 0.4$ & $3.4 \pm 0.3$ & $1.8 \pm 0.2$ \\
\hline & B & $8.0 \pm 0.0$ & $9.2 \pm 0.3$ & $>6.2$ & $7.2 \pm 0.1$ & $4.2 \pm 0.1$ & $<1$ \\
\hline \multirow[t]{2}{*}{9} & A & $8.9 \pm 0.1$ & $9.0 \pm 0.1$ & $5.8 \pm 0.3$ & $>7.2$ & $6.2 \pm 0.1$ & $3.6 \pm 0.2$ \\
\hline & B & $9.9 \pm 0.2$ & $>10.5$ & $>6.2$ & $>7.2$ & $5.4 \pm 0.1$ & $1.3^{\mathrm{a}}$ \\
\hline \multirow[t]{2}{*}{10} & A & $8.1 \pm 0.0$ & $8.6 \pm 0.0$ & $6.1 \pm 0.6$ & $6.3 \pm 0.1$ & $6.2 \pm 0.1$ & $4.2 \pm 0.4$ \\
\hline & B & $7.8 \pm 0.0$ & $9.0 \pm 0.1$ & $7.2 \pm 0.1$ & $8.1 \pm 0.2$ & $3.4 \pm 0.3$ & $2.3 \pm 0.4$ \\
\hline \multirow[t]{2}{*}{11} & A & $8.9 \pm 0.1$ & $8.8 \pm 0.1$ & $5.9 \pm 0.1$ & $>7.2$ & $3.5 \pm 0.1$ & $3.7 \pm 0.5$ \\
\hline & B & $8.7 \pm 0.1$ & $8.8 \pm 0.1$ & $>7.2$ & $>7.2$ & & $2.1^{\mathrm{a}}$ \\
\hline \multirow[t]{2}{*}{12} & A & $8.1 \pm 0.1$ & $8.1 \pm 0.0$ & $>6.2$ & $>7.2$ & $6.4 \pm 0.2$ & $4.3 \pm 0.9$ \\
\hline & B & $9.4 \pm 0.0$ & $9.2 \pm 0.1$ & $>7.2$ & $>8.2$ & $5.7 \pm 0.5$ & $5.6 \pm 0.2$ \\
\hline
\end{tabular}

ND, not determined.

a Value obtained for one independent sample. Not detected in the other sample.

2004; Papamanoli, Kotzekidou, Tzanetakis, \& LitopoulouTzanetaki, 2002; Papamanoli, Tzanetakis, LitopoulouTzanetaki, \& Kotzekidou, 2003).
In addition to LAB and members of the Micrococcacae, yeast and moulds also play an important role in the development of the organoleptic characteristics of fermented 
Table 5

Microbiological characterization of alheira: commonly controlled microbial safety parameters

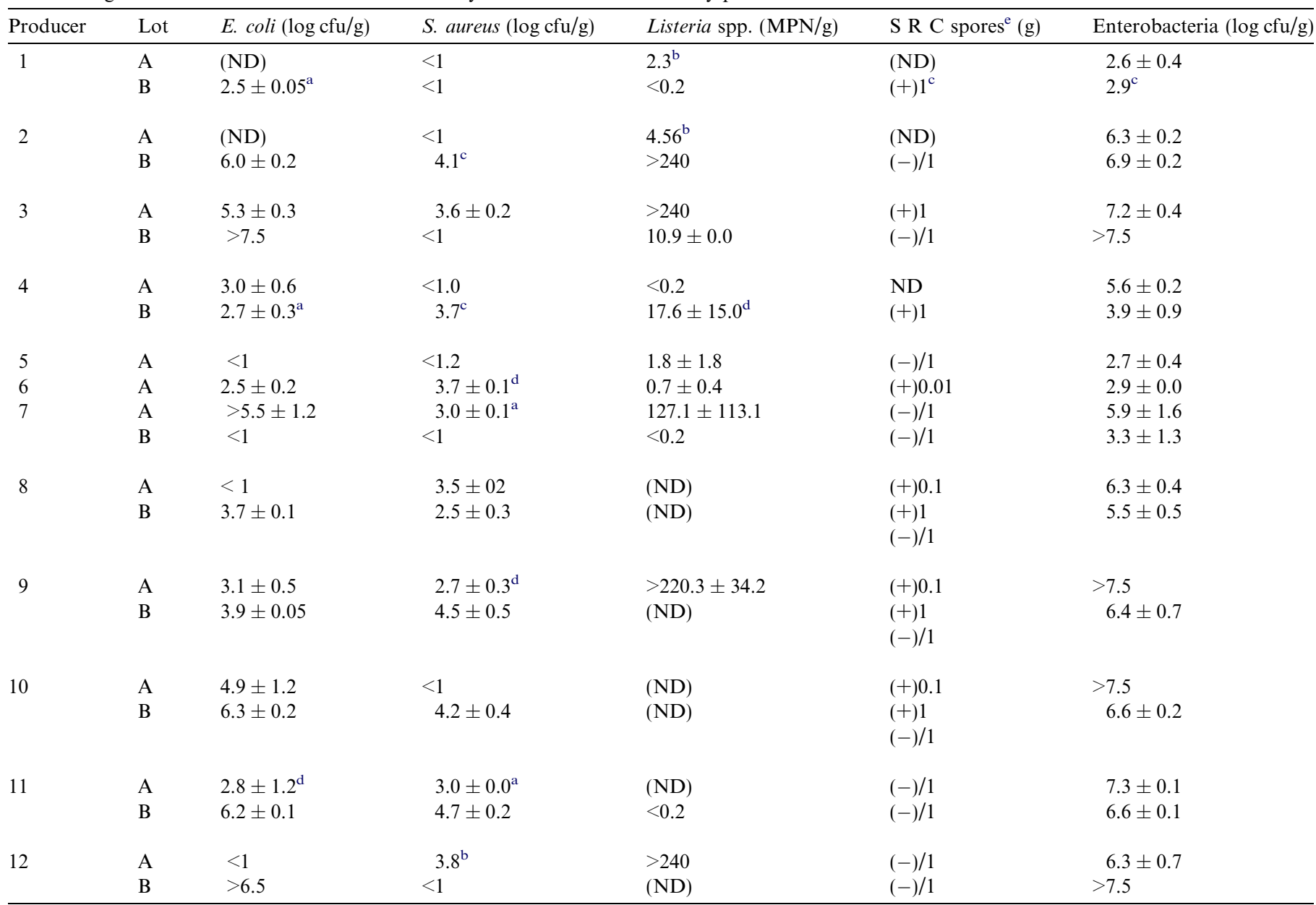

ND, not determined.

${ }^{a}$ Media of two independent samples. Not detected in the two other independent samples.

${ }^{b}$ Value obtained for one independent sample. Not detected in the other sample.

${ }^{c}$ Value obtained for one sample. Not detected in the other three samples.

${ }^{\mathrm{d}}$ Media of three independent samples. Not detected in the other independent sample.

e Analyzed in $0.01,0.1$ and $1 \mathrm{~g} ;(+)$, positive in; $(-)$, negative in.

sausages (Mauriello, Casaburi, Blaiotta, \& Villani, 2004). Yeasts and moulds were isolated from most of the products ranging from $<1 \log$ to $6.4 \log$ and from $<1 \log$ to $5.6 \log \mathrm{cfu} / \mathrm{g}$, respectively.

Enterococci counts were higher than $6.5 \log \mathrm{cfu} / \mathrm{g}$ in most of the products. Strains of this genus are frequently isolated from fermented sausages, especially in high $\mathrm{pH}$ products where no competitive starter cultures are used (Hugas, Garriga, \& Aymerich, 2003). The metabolic activity of enterococci in the fermenting sausage matrix have not been studied in detail, however, they certainly contribute to sausage aromatization by their glycolytic, proteolytic and lipolytic activities (Sarantinopoulos et al., 2001). The presence of enterococci in foods however, is a concern, as many strains possess virulence traits (Franz, Stiles, Schleifer, \& Holzapfel, 2003).

Concerning the indicator organisms investigated, it can be inferred that most of the alheiras were produced under deficient hygienic conditions leading to post-process contamination after boiling of the meats (Table 5). It should be pointed out that according to the guidelines for the microbiological quality of fermented meats published by Gilbert et al. (2000), most of the samples tested would be considered unsatisfactory as Enterobacteriaceae and E. coli counts were higher than $4 \log$ and $2 \log \mathrm{cfu} / \mathrm{g}$, respectively. The detection of Listeria spp. in some samples, an important indicator of plant hygiene, due to their ubiquitous nature, points to the possibility of product contamination with the pathogenic species $L$. monocytogenes. According to these guidelines, four samples should be considered as unacceptable/potentially hazardous as coagulase-positive staphylococci were found in a concentration higher than $4 \log \mathrm{cfu} / \mathrm{g}$ (Gilbert et al., 2000). In general, the results obtained have shown that the optimization of hygienic procedures in the production process is necessary to improve the quality and safety of alheiras. 
Further work will be carried out in order to evaluate the incidence of specific pathogens and in order to identify the main sources of product contamination.

\section{Acknowledgement}

This work was supported by FCT/FEDER Project POCTI/AGG/39587/2001.

\section{References}

Ansorena, D., Montel, M. C., Rokka, M., Talon, R., Eerola, S., Rizzo, A., et al. (2002). Analysis of biogenic amines in northern and southern European sausages and role of flora in amine production. Meat Science, 61, 141-147.

AOAC (1997). Official methods of analysis (16th ed.). Arlington, Virginia: Association of Official Analytical Chemists.

Coïsson, J. D., Cerutti, C., Travaglia, F., \& Arlorio, M. (2004). Production of biogenic amines in Salami italiani alla cacciatore PDO. Meat Science, 67, 343-349.

Directorate-General Health and Consumer Protection (2004). Assessment of the dietary exposure to arsenic, cadmium, lead and mercury of the population of the EU member states.

Drosinos, E. H., Mataragas, M., Xiraphi, N., Moschonas, G., Gaitis, F., \& Metaxopoulos, J. (2005). Characterization of the microbial flora from a traditional Greek fermented sausage. Meat Science, 69, $307-317$.

ECS (2002). Foodstuffs - determination of trace elements - determination of mercury by cold-vapour atomic absorption spectrometry (CVAAS) after pressure digestion. European Standard EN 13806.

ECS (2003). Foodstuffs - determination of trace elements - determination of lead, cadmium, zinc, copper, iron and chromium by atomic absorption spectrometry (AAS) after dry ashing. European Standard EN 14082.

European Commission (1995). Council Directive 95/2 of 20 February 1995 on food additives other than colours and sweeteners. Official Journal of the European Communities, L6, March 16 2001, 1, 1995.

European Commission (2001). Council Regulation No. 466 of 8 March 2001 on the setting maximum levels of certain contaminants in foodstuffs. Official Journal of the European Communities, L77, 1-13, March 16, 2001.

Franz, C. M. A. P., Stiles, M. E., Schleifer, K. H., \& Holzapfel, W. H. (2003). Enterococci in foods - a conundrum for food safety. International Journal of Food Microbiology, 88, 105-122.

Gilbert, R. J., de Louvois, J., Donovan, T., Little, C., Nye, K., Ribeiro, C. D., et al. (2000). Guidelines for the microbiological quality of some ready-to-eat foods sampled at the point of sale. PHLS advisory committee for food and dairy products. Communicable Disease and Public Health, 3, 163-167.

Hernández-Jover, T., Izquierdo-Pulido, M., Veciana-Nogués, M. T., Mariné-Font, A., \& Vidal-Carou, M. C. (1997). Biogenic amine and polyamine contents in meat and meat products. Journal of Agricultural and Food Chemistry, 44, 3097-3101.

Hugas, M., Garriga, M., \& Aymerich, M. T. (2003). Functionality of enterocci in meat products. International Journal of Food Microbiology, $88,223-233$.
IPQ (1986). Food microbiology. General rules for identifying reducing clostridium sulphite spores. Portuguese Standard NP 2262.

ISO (1975a). Meat and meat products - determination of nitrite content (reference method). International Standard 2918.

ISO (1975b). Meat and meat products - determination of nitrate content (reference method). International Standard 3091.

ISO (1996a). Meat and meat products - determination of chloride content - part 2: potentiometric method. International Standard 1841-2.

ISO (1996b). Microbiology of food and animal feeding stuffs - horizontal method for the detection and enumeration of Listeria monocytogenes. International Standard 11290-1.

ISO (1997). Meat and meat products - determination of moisture content (reference method). International Standard 1442.

ISO (2000). Microbiology of food and animal feeding stuffs - horizontal methods for the detection and enumeration of Enterobacteriaceae part 2: colony-count method. International Standard 21528-2.

Joosten, H. M. L. J. (1988). Conditions allowing the formation of biogenic amine in cheese: 4 . Factors influencing the amounts formed. Netherlands Milk and Dairy Journal, 41, 329-357.

Komprda, T., Smělá, D., Pechová, P., Kalhotka, J., Štencl, J., \& Klejdus, B. (2004). Effect of starter culture, spice mix and storage time and temperature on biogenic amine content of dry fermented sausages. Meat Science, 67, 607-616.

Mauriello, G., Casaburi, A., Blaiotta, G., \& Villani, F. (2004). Isolation and technological properties of coagulase negative staphylococci from fermented sausages of Southern Italy. Meat Science, 67, 149-158.

Moore, J. E. (2004). Gastrointestinal outbreaks associated with fermented meats. Meat Science, 67, 565-568.

Moretti, V. M., Madonia, G., Diaferia, C., Mentasti, T., Paleari, M. A., Panseri, S., et al. (2004). Chemical and microbiological parameters and sensory attributes of a typical Sicilian salami ripened in different conditions. Meat Science, 66, 845-854.

Papamanoli, E., Kotzekidou, P., Tzanetakis, N., \& Litopoulou-Tzanetaki, E. (2002). Characterization of Micrococcaceae isolated from dry fermented sausage. Food Microbiology, 19, 441-449.

Papamanoli, E., Tzanetakis, N., Litopoulou-Tzanetaki, E., \& Kotzekidou, P. (2003). Characterization of lactic acid bacteria isolated from a Greek dry-fermented sausage in respect to their technological and probiotic properties. Meat Science, 65, 859-867.

Santos, E. M., Jaime, I., Rovira, J., Lyhs, U., Korkeala, H., \& Björkroth, J. (2005). Characterization and identification of lactic acid bacteria in morcilla de Burgos. International Journal of Food Microbiology, 97, 285-296.

Sarantinopoulos, P., Andrighetto, C., Georgalaki, M. D., Rea, M. C., Lombardi, A., Cogan, T. M., et al. (2001). Biochemical properties of enterococci relevant to their technological performance. International Dairy Journal, 11, 621-647.

Silla-Santos, M. H. (1996). Biogenic amines: their importance in foods. International Journal of Food Microbiology, 29, 213-231.

Slack, P.T. (1997). Analytical methods manual, 3rd ed. Leatherhead Food R.A.

Suzzi, G., \& Gardini, F. (2003). Biogenic amines in dry fermented sausages: a review. International Journal of Food Microbiology, 88, 41-54.

ten Brink, B., Damink, C., Joosten, H. M. L. J., \& in 't Veld, J. H. J. (1990). Occurrence and formation of biologically active amines in foods. International Journal of Food Microbiology, 11, 73-84.

Tschabrun, R., Sick, K., Bauer, F., \& Kranner, P. (1990). Bildung von histamin in schnittfesten Rohwursten. Fleischwirtsch, 70(4), 448-452. 